\title{
EVALUASI INSTALASI PLUMBING AIR BERSIH RUMAH TIPE 42 MENGGUNAKAN PIPE FLOW EXPERT BERDASARKAN SNI 03-7065-2005 DAN BS 6700
}

\author{
Pekik Mahardhika \\ Program Studi D4 Teknik Perpipaan, Politeknik Perkapalan Negeri Surabaya \\ Jl. Teknik Kimia Kampus ITS, Keputih Sukolilo Surabaya 60111 \\ Email: pekikmahardhika@ppns.ac.id
}

\begin{abstract}
Abstrak
Sistem plumbing adalah sistem perpipaan yang berhubungan dengan penyaluran air dalam suatu bangunan rumah, gedung, dan lain-lain. Saat ini kebutuhan instalasi plumbing berkembang pesat seiring permintaan pembangunan perumahan yang signifikan. Sistem plumbing air bersih bertujuan menyediakan penyaluran air bersih untuk kebutuhan pemakai rumah tipe 42 di Perumahan Kartika Chandra Sidoarjo. Permasalahan yang sering terjadi dalam sistem plumbing adalah tidak diketahuinya tekanan, laju aliran, kecepatan aliran, dan kerugian head-head pada pipa sehingga distribusi air disetiap cabang pipa belum tentu sesuai persyaratan SNI 03-7065-2005 dan BS 6700. Oleh karena itu perlu mengevaluasi instalasi sistem plumbing air bersih terhadap persyaratan SNI 03-7065-2005 dan BS 6700 . Parameter utama meliputi kebutuhan air bersih, tekanan, laju aliran, kecepatan aliran, dan tipe aliran. Hasil evaluasi menunjukkan bahwa laju aliran belum memenuhi minimum persyaratan SNI 03-7065-2005 dan BS 6700, tekanan fluida belum memenuhi minimum persyaratan SNI 03-7065-2005 dan BS 6700, tetapi kecepatan aliran masih memenuhi persyaratan SNI 03-7065-2005. Aliran fluida dalam pipa merupakan jenis aliran turbulen yang memiliki $\operatorname{Re}>4000$.
\end{abstract}

Kata Kunci: BS 6700, Debit, Kecepatan aliran, SNI 03-7065-2005, Tekanan

\begin{abstract}
Plumbing system is a piping system related with the water supply in a building of houses, buildings, and others. Currently, the need for plumbing installations is growing rapidly as demand for housing projects is significant. This water supply system provides clean water supply for the needs of housing users of type 42 in Housing Kartika Chandra Sidoarjo. The problems that often occur in the plumbing system is unrecognized of pressure, flow rate, velocity, and head losses on the pipe so that the distribution of water in each branch of the pipe is not comply with SNI 03-70652005 and BS 6700 criteria. Therefore it is necessary to evaluate the installation of water supply system to SNI 037065-2005 and BS 6700 requirements. The main parameters include water supply requirements, pressure, flow rate, velocity and type of flow. The results of the evaluation is the flow rate has not comply with minimum requirements of SNI 03-7065-2005 and BS 6700, the pressure has not comply with requirements of SNI 03-7065-2005 and BS 6700, but the velocity still comply with requirements SNI 03-7065-2005. Fluid flow in pipe is a turbulent flow type with Re > 4000 .
\end{abstract}

Keywords: BS6700, Flow rate, Velocity, SNI 03-7065-2005, Pressure

\section{PENDAHULUAN}

Sistem plumbing adalah sistem perpipaan yang berhubungan dengan penyaluran air dalam suatu bangunan rumah, gedung, hotel, dan lain-lain. Saat ini kebutuhan instalasi plumbing berkembang pesat seiring permintaan pembangunan perumahan yang signifikan. Sistem plumbing memiliki 2 sub sistem utama yaitu sistem air bersih dan sistem air kotor [1]. Perancangan dan instalasi plumbing tidak boleh sembarangan. Hal ini bertujuan untuk menghindari adanya kegagalan sistem seperti kurangnya tekanan dan kecepatan aliran fluida. Keadaan tersebut bisa mengakibatkan distribusi air yang mengalir tidak maksimal di setiap cabang pipa dikarenakan tidak diketahuinya tekanan, debit, kecepatan aliran, dan kerugian head-head pipa yang tidak sesuai minimum persyaratan SNI 03-7065-2005 dan BS 6700. Standar dari SNI 03-7065-2005 atau BS 6700 tersebut memiliki peran penting dalam penentuan metode dalam perancangan, sehingga permasalahan tidak terjadi. Hal ini dimaksudkan untuk menjaga kualitas dan sebagai bukti keunggulan dari suatu bangunan. Objek penelitian pada instalasi sistem plumbing adalah sampel salah satu rumah tipe 42 di Perumahan Kartika Chandra Sidoarjo.

\section{METODE}

\subsection{Bahan dan Peralatan}

Dalam penelitian ini bahan dan peralatan yang digunakan adalah:

a. Software Pipe Flow Expert 


\section{b. Gambar isometri instalasi sistem plumbing}

\subsection{Tinjauan Pustaka}

\section{- $\quad$ Sistem Plumbing}

Alat plumbing adalah semua peralatan yang dipasang di dalam maupun di luar gedung untuk menyediakan air panas atau air dingin, dan untuk menyalurkan air buangan [2]. Fungsi dari peralatan plumbing adalah :

- Sistem Penyediaan air bersih, menyediakan air bersih ke tempat-tempat yang dikehendaki dengan kualitas, kuantitas, dan tekanan yang cukup.

- Penyaluran air buangan, membuang air kotor dari tempat-tempat tertentu tanpa mencemari sistem yang lain serta mencegah masuknya udara tidak sedap dan air kotor ke dalam ruangan.

- Penyediaan air untuk pemadam kebakaran, menyediakan air dengan kuantitas yang cukup dan mudah operasinya apabila terjadi kebakaran.

- Penyediaan air panas, menyediakan air panas yang cukup dan tidak mempengaruhi lingkungan sekitarnya.

Pemakaian/kebutuhan air rata-rata dapat diketahui dengan menggunakan perhitungan sebagai berikut:

Pemakaian air dalam satu hari (Q1) adalah

$Q 1=$ Jumlah penghuni $x$ Pemakaian air (1)

Diperkirakan tambahan pemakaian air untuk menyiram tanaman, mesin cuci, dan lain-lain sehingga untuk pemakaian air rata-rata perhari maksimal $\left(\mathrm{Qd}_{\max }\right)$ :

$Q d \max =Q 1+(20 \% Q 1)$

Q1 didasarkan pada tabel kebutuhan air perhari oleh SNI 03-7065-2005 untuk rumah tinggal adalah 120 liter/penghuni/hari [3]. Berdasarkan BS 6700 kebutuhan air perhari untuk rumah tinggal adalah 120 liter/penghuni/hari [4].

Aliran laminer adalah jenis aliran dengan kecepatan rendah sehingga ketika fluida mengalir seolah-olah terdiri dari bertumpuk-tumpuk lapisan dan memiliki $\mathrm{Re}<2300$. Aliran turbulen transisi adalah jenis aliran dengan kecepatan sedang sehingga terjadi transisi antara lain rata (laminer) menuju aliran deras (turbulen) dan memiliki $\operatorname{Re}=2300-4000$ (dimana aliran dapat bersifat laminar atau turbulen tergantung pada kondisi pipa dan aliran). Aliran turbulen adalah jenis aliran dengan kecepatan tinggi sehingga pertikelpertikel fluida bergerak dengan lintasan yang tidak teratur dan memiliki Re $>4000$ [5]. Untuk menentukan aliran laminer, transisi atau turbulen dapat ditentukan dengan persamaan bilangan Reynolds berikut: [6]

$$
R e=\frac{V \cdot D \cdot \rho}{\mu}
$$

$$
\begin{array}{ll}
\mathrm{Re} & =\text { Bilangan Reynold } \\
\mathrm{V} & =\operatorname{Kecepatan} \text { aliran }(\mathrm{m} / \mathrm{s}) \\
\mathrm{D} & =\text { Diameter dalam pipa }(\mathrm{m}) \\
\rho & =\text { Massa jenis fluida }\left(\mathrm{kg} / \mathrm{m}^{3}\right) \\
\mu & =\text { Viskositas fluida }(\mathrm{kg} . \mathrm{m} / \mathrm{s})
\end{array}
$$

Pada SNI 03-7065-2005 terdapat persyaratan untuk tekanan minimum yang diperlukan alat plumbing sebagai berikut: [3]
Tabel 1. Tekanan minimum yang diperlukan alat plumbing

\begin{tabular}{|c|l|c|}
\hline No & \multicolumn{1}{|c|}{$\begin{array}{c}\text { Nama Alat } \\
\text { Plumbing }\end{array}$} & $\begin{array}{c}\text { Tekanan yang } \\
\text { diperlukan }\left(\mathrm{kg} / \mathrm{cm}^{2}\right)\end{array}$ \\
\hline 1 & $\begin{array}{l}\text { Katup gelontor } \\
\text { kloset }\end{array}$ & 0,7 \\
\hline 2 & $\begin{array}{l}\text { Katup gelontor } \\
\text { peturasan }\end{array}$ & 0,4 \\
\hline 3 & $\begin{array}{l}\text { Kran yang menutup } \\
\text { otomatik }\end{array}$ \\
\hline 4 & $\begin{array}{l}\text { Pancuran mandi, } \\
\text { dengan pancaran air } \\
\text { halus }\end{array}$ & 0,7 \\
\hline 5 & $\begin{array}{l}\text { Pancuran mandi } \\
\text { biasa }\end{array}$ \\
\hline 6 & Kran biasa & 0,35 \\
\hline
\end{tabular}

Persyaratan tekanan untuk alat plumbing yang diatur menurut BS 6700 yaitu 0,5 -1,5 bar [4].

Pada SNI 03-7065-2005 terdapat perkiraan beban kebutuhan air untuk Unit Beban Alat Plumbing (UBAP) sebagai berikut: [3]
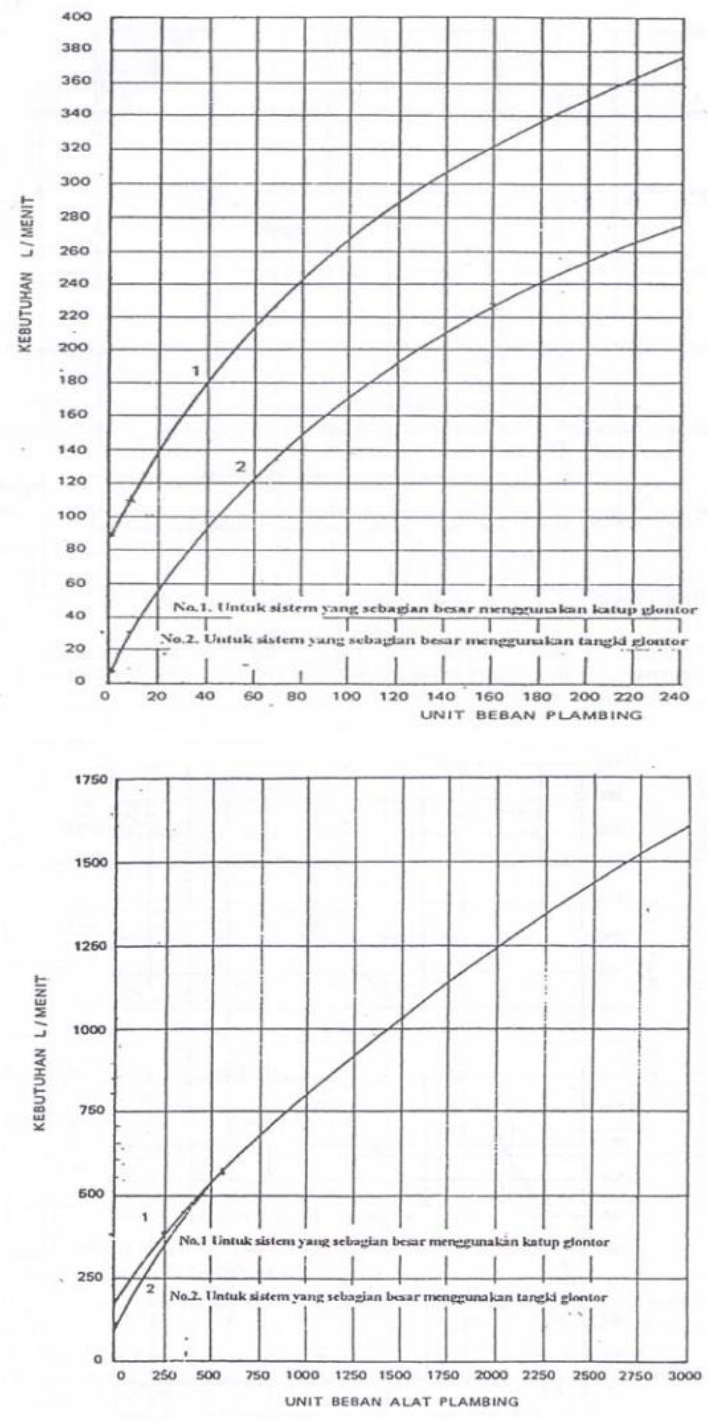

Gambar 1. Kurva perkiraan beban kebutuhan air untuk UBAP sampai dengan 3000 
Untuk setiap alat plumbing ditetapkan suatu unit beban berdasarkan BS 6700 kemudian diproyeksikan ke gambar 2 untuk mengetahui laju aliran. Hubungan antara Unit Beban Alat Plumbing dengan laju aliran berdasarkan BS 6700 ditunjukkan pada gambar 2 [4].

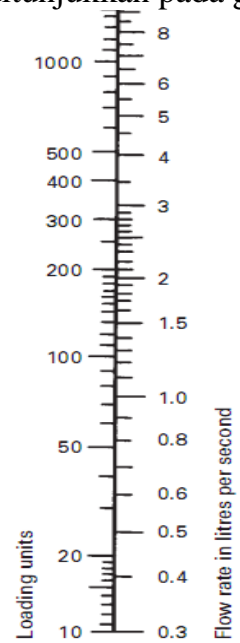

Gambar 2. Hubungan Antara Unit Beban Alat Plumbing Dengan Laju Aliran. (untuk unit beban sampai 1000)

Pada SNI 03-7065-2005 terdapat ketentuan umum sistem penyediaan air minum dalam hal kecepatan aliran dalam pipa yaitu minimum $0,9 \mathrm{~m} /$ detik dan maksimal $2 \mathrm{~m} /$ detik. [3]

Perhitungan persamaan kontinuitas dapat dihitung dengan persamaan berikut: [7]

$$
Q 1=Q 2
$$

A1. $V 1=A 2 . V 2$

Keterangan:

$$
\begin{array}{ll}
\mathrm{Q} & =\text { Debit }\left(\mathrm{m}^{3} / \mathrm{s}\right) \\
\mathrm{A} & =\text { Luas Penampang }\left(\mathrm{m}^{2}\right) \\
\mathrm{V} & =\text { Kecepatan aliran }(\mathrm{m} / \mathrm{s})
\end{array}
$$

Head loss mayor dapat terjadi karena adanya gesekan antara aliran fluida yang mengalir dengan suatu dinding pipa. Pada umumnya kerugian ini dipengaruhi oleh panjang pipa. Head loss mayor dapat dihitung dengan menggunakan persamaan DarcyWeisbach berikut ini: [8]

$h f=f \frac{L}{D} \frac{V^{2}}{2 \cdot g}$

Head loss minor dapat terjadi karena adanya sambungan pipa, seperti katup (valve), belokan (elbow), saringan (strainer), percabangan (tee), dan lain-lain. Head loss minor dapat dihitung dengan menggunakan persamaan berikut: [8]

$\mathrm{h} f=\mathrm{n} \times k \frac{V^{2}}{2 \times g}$

\subsection{Metode}

Metode penelitian adalah langkah-langkah yang dijadikan panduan untuk melakukan penelitian, agar dapat diperoleh hasil yang baik untuk mencapai tujuan penelitian yang direncanakan. Langkah-langkah pelaksanaan penelitian pada diagram berikut ini:

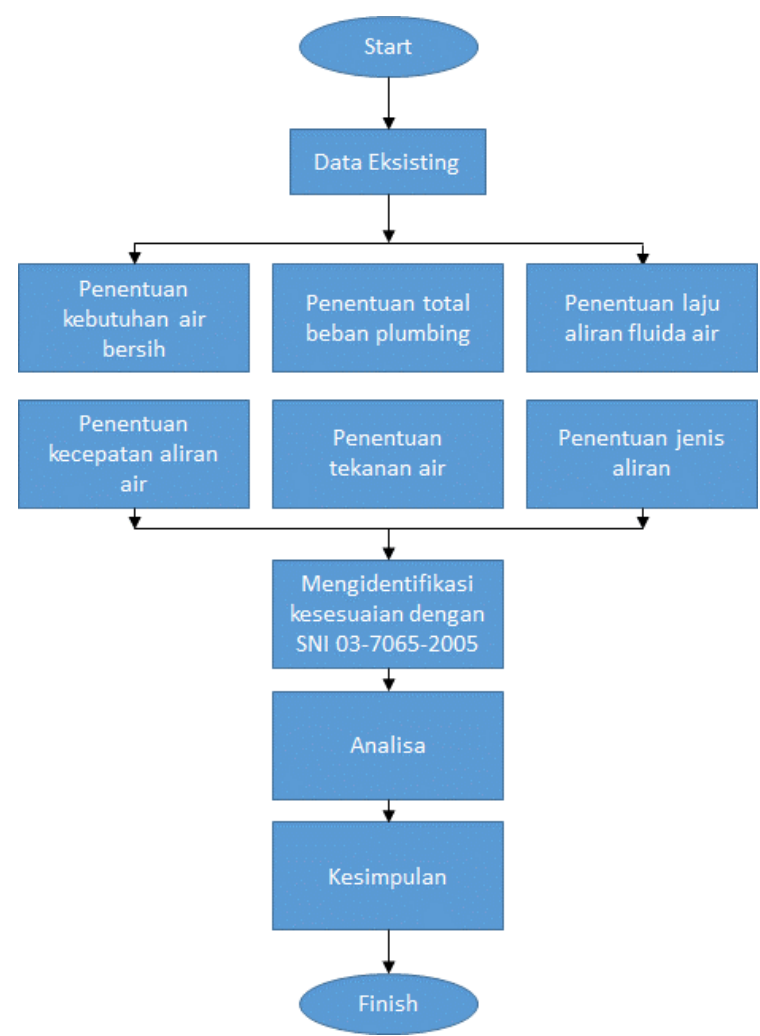

Gambar 3. Diagram Alir Penelitian

Dalam penelitian ini terdapat data pendukung yaitu gambar isometri instalasi plumbing air bersih rumah tipe 42 sebagai berikut:

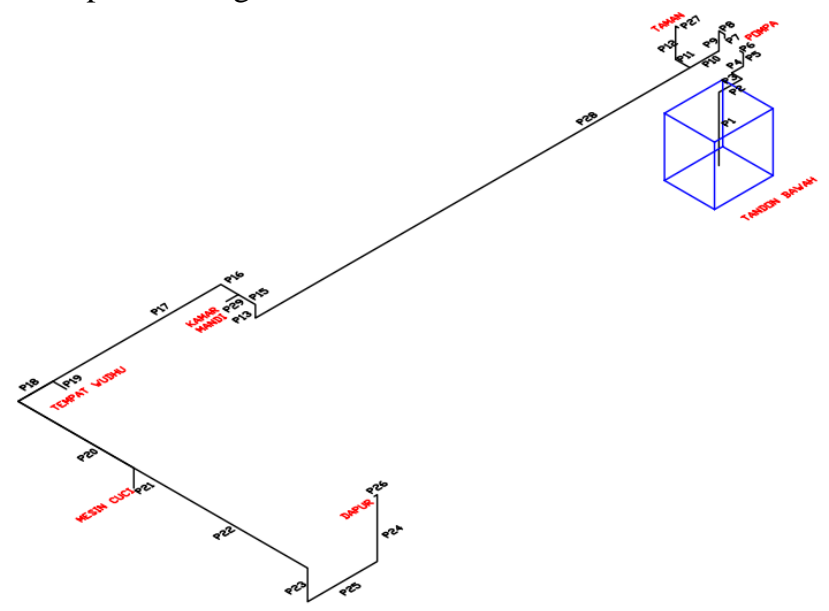

Gambar 4. Isometri Instalasi Sistem Plumbing

\section{HASIL DAN PEMBAHASAN}

\subsection{Data Instalasi Plumbing}

Berikut data pada software pipe expert untuk evaluasi instalasi plumbing.

Data fluida: fluidanya adalah air $\left(\mathrm{H}_{2} \mathrm{O}\right)$ dengan massa jenis $997 \mathrm{~kg} / \mathrm{m}^{3}$ dengan vapour pressure 0,0317 bar. Data pompa: Pompa Shimizu 130 bit, laju aliran in/out $0,003 \mathrm{~m}^{3} /$ detik, kecepatan aliran 0,538 m/detik, head pompa $23,417 \mathrm{~m}$.

Data pipa: Material pipa adalah PVC 0,5 inch dengan roughness 0,005 dan galvanis 0,5 inch dengan roughness 0,150 (pada $\mathrm{P} 12$ dan $\mathrm{P} 27$ ). 


\subsection{Hasil}

Dari hasil perhitungan dan komputasi pipe flow expert didapatkan hasil sebagai berikut:

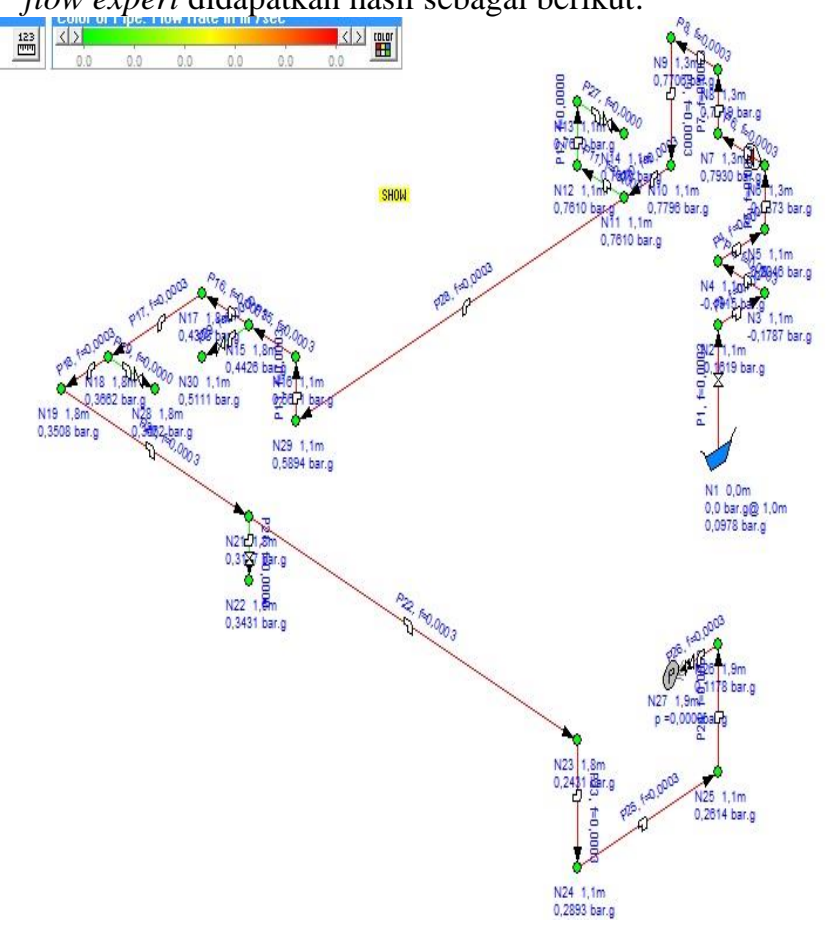

Gambar 5. Komputasi instalasi plumbing menggunakan pipe flow expert

\section{- Penentuan kebutuhan air}

Berdasarkan pada tabel kebutuhan air perhari oleh SNI 03-7065-2005 dan BS6700 untuk rumah tinggal adalah 120 liter/penghuni/hari, kemudian dihitung menggunakan persamaan 1 dan 2. Perhitungannya sebagai berikut:

$$
\begin{aligned}
& \text { Q1 = Jumlah penghuni } x \text { Pemakaian air } \\
& \text { = } 3 \text { penghuni x } 120 \text { liter/penghuni/hari } \\
& \text { = } 360 \text { liter/hari }
\end{aligned}
$$

Pemakaian air rata-rata perhari maksimal:

$$
\begin{aligned}
Q d & =Q 1+(20 \% Q 1) \\
& =360 \text { liter/hari }+(20 \% \times 360 \text { liter/hari }) \\
& =432 \text { liter/hari }
\end{aligned}
$$

\section{- Penentuan beban total plumbing}

Pada penentuan beban total alat plumbing bahwa jenis alat plumbing yang digunakan adalah bak mandi, bak cuci dapur, bak cuci pakaian, dan kran. Hasil perhitungan Total UBAP berdasarkan SNI 03-70652005 dan BS 6700 pada tabel 2 dan 3 berikut:

Tabel 2. Perhitungan total unit beban alat plumbing (SNI 03-7065-2005)

\begin{tabular}{|l|c|c|c|}
\hline $\begin{array}{c}\text { Nama Alat } \\
\text { Plumbing }\end{array}$ & $\begin{array}{c}\text { Unit } \\
\text { Beban }\end{array}$ & Jumlah & $\begin{array}{c}\text { Total } \\
\text { Beban }\end{array}$ \\
\hline Bak mandi & 2 & 1 & 2 \\
\hline Bak cuci dapur & 2 & 1 & 2 \\
\hline $\begin{array}{l}\text { Bak cuci } \\
\text { pakaian }\end{array}$ & 2 & 1 & 2 \\
\hline Kran Total UBAP & 2 & - \\
\hline \multicolumn{2}{|r|}{} \\
\hline
\end{tabular}

Tabel 3. Perhitungan total unit beban alat plumbing (BS6700)

\begin{tabular}{|l|c|c|c|}
\hline $\begin{array}{c}\text { Nama Alat } \\
\text { Plumbing }\end{array}$ & $\begin{array}{c}\text { Unit } \\
\text { Beban }\end{array}$ & Jumlah & $\begin{array}{c}\text { Total } \\
\text { Beban }\end{array}$ \\
\hline Bak mandi & 10 & 1 & 10 \\
\hline $\begin{array}{l}\text { Bak cuci } \\
\text { dapur }\end{array}$ & 3 & 1 & 3 \\
\hline $\begin{array}{l}\text { Bak cuci } \\
\text { pakaian }\end{array}$ & 3 & 1 & 3 \\
\hline Kran & 1,5 & 2 & 3 \\
\hline \multicolumn{3}{|c|}{ Total UBAP } & 19 \\
\hline
\end{tabular}

\section{- Penentuan laju aliran fluida}

Hasil total UBAP diplot ke dalam gambar 6 berikut:

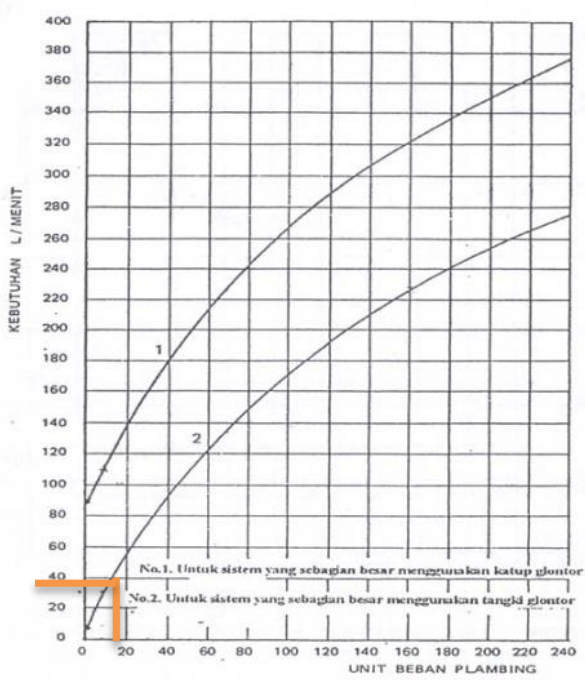

Gambar 6. Plot hasil Total UBAP (SNI 03-70652005)

Kurva pada gambar 6 tersebut memberikan hubungan antara jumlah unit beban alat plumbing dengan kebutuhan laju aliran fluida, dengan memasukkan faktor kemungkinan penggunaan serentak dari alat-alat plumbing. Dari gambar 6 hasil plot didapatkan minimum kebutuhan laju aliran penggunaan serentak dari alat-alat plumbing sebesar 38 liter/menit $\left(0,00063 \mathrm{~m}^{3} /\right.$ detik $)$ berdasarkan persyaratan SNI 03-7065-2005.

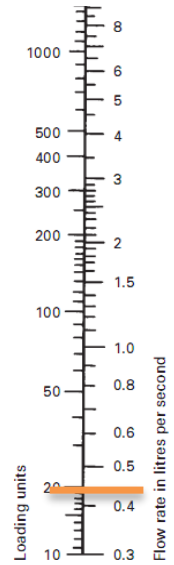

Gambar 7. Plot hasil Total UBAP (BS 6700) 
Dari gambar 7 hasil plot hubungan antara Unit Beban Alat Plumbing (UBAP) dengan laju aliran didapatkan minimum kebutuhan laju aliran penggunaan serentak pada alat-alat plumbing sebesar 0,44 liter/detik $\left(0,00044 \mathrm{~m}^{3} /\right.$ detik $)$ berdasarkan persyaratan BS 6700. Kemudian pada tabel 4 menunjukkan data hasil komputasi pipe flow expert untuk laju aliran fluida pada saat penggunaan serentak dari alat-alat plumbing.

Tabel 4. Data hasil komputasi untuk laju aliran fluida

\begin{tabular}{|c|c|c|}
\hline No & No.Pipa & $\begin{array}{c}\text { Laju aliran } \\
\left(\mathrm{m}^{3} / \text { detik }\right)\end{array}$ \\
\hline 1 & P1-P29 & 0,0003 \\
\hline
\end{tabular}

\section{- Penentuan kecepatan aliran fluida}

Pada tabel 5 menunjukkan data hasil komputasi pipe flow expert untuk kecepatan aliran fluida pada saat penggunaan dari alat-alat plumbing serentak.

Tabel 5. Data hasil komputasi untuk kecepatan aliran fluida

\begin{tabular}{|c|c|c|}
\hline No & No.Pipa & $\begin{array}{c}\text { Kecepatan aliran } \\
\text { fluida (m/detik) }\end{array}$ \\
\hline 1 & P1-P29 & 1,530 \\
\hline
\end{tabular}

\section{- Penentuan tekanan fluida}

Pada tabel 6 menunjukkan data hasil komputasi pipe flow expert untuk tekanan fluida pada saat penggunaan dari alat-alat plumbing serentak. Jenis alat plumbing yang digunakan adalah bak mandi, bak cuci dapur, bak cuci pakaian, dan kran yang sesuai tabel 2 .

Tabel 6. Data hasil komputasi untuk tekanan fluida

\begin{tabular}{|c|l|c|}
\hline No & \multicolumn{1}{|c|}{ Node Pipa } & $\begin{array}{c}\text { Tekanan } \\
\text { fluida (bar.g) }\end{array}$ \\
\hline 1 & Node 14 (kran taman) & 0,7050 \\
\hline 2 & Node 30 (bak mandi) & 0,5111 \\
\hline 3 & Node 28 (kran wudhu) & 0,3662 \\
\hline 4 & $\begin{array}{l}\text { Node 22 (bak cuci } \\
\text { pakaian) }\end{array}$ & 0,3431 \\
\hline 5 & $\begin{array}{l}\text { Node 27 (bak cuci } \\
\text { dapur) }\end{array}$ & 0,1178 \\
\hline
\end{tabular}

\section{- Penentuan jenis aliran fluida}

Berdasarkan persamaan 3 didapatkan jenis aliran fluida. Perhitungan menggunakan persamaan 3 untuk mengetahui aliran yang terjadi apakah aliran laminer atau aliran turbulen. Pada tabel 7 menunjukkan data hasil perhitungan untuk jenis aliran fluida.

Tabel 7. Data hasil perhitungan jenis aliran fluida

\begin{tabular}{|c|c|c|c|}
\hline No & No.Pipa & $\begin{array}{c}\text { Reynold } \\
\text { Number }\end{array}$ & $\begin{array}{c}\text { Jenis } \\
\text { Aliran } \\
\text { Fluida }\end{array}$ \\
\hline 1 & P1 - P29 & 27078 & Turbulen \\
\hline
\end{tabular}

\subsection{Pembahasan}

Dari hasil perhitungan dan komputasi menggunakan software pipe flow expert didapatkan laju aliran kebutuhan dan laju aliran pada saat penggunaan dari alat-alat plumbing serentak. Data menunjukkan bahwa nilai laju aliran serentak yang terjadi yaitu 0,0003 $\mathrm{m}^{3} /$ detik. Nilai laju aliran serentak tersebut belum memenuhi minimum persyaratan laju aliran kebutuhan berdasarkan SNI 03-7065-2005 yaitu 0,00063 m³/detik dan BS 6700 yaitu $0,00044 \mathrm{~m}^{3} /$ detik. Perbandingan minimum laju aliran kebutuhan dengan laju aliran serentak (software) ditunjukkan pada tabel 8.

Tabel 8. Perbandingan minimum laju aliran kebutuhan dengan laju aliran serentak (software)

\begin{tabular}{|c|c|c|c|}
\hline No & $\begin{array}{c}\text { Minimum } \\
\text { Laju aliran } \\
\text { kebutuhan } \\
\end{array}$ & $\begin{array}{c}\text { Minimum } \\
\text { Laju aliran } \\
\left(\mathrm{m}^{3} / \text { detik }\right)- \\
\text { kNI 03-7065- } \\
\left(\mathrm{m}^{3} / \text { detik }\right) \\
-\mathrm{BS} 6700\end{array}$ & $\begin{array}{c}\text { Laju aliran } \\
\text { serentak } \\
\left(\mathrm{m}^{3} / \text { detik }\right) \\
\text { - software }\end{array}$ \\
\hline 1 & 0,0006 & & \\
\hline
\end{tabular}

Berdasarkan hasil komputasi tabel 5 menunjukkan bahwa nilai kecepatan aliran (software) yaitu $1,530 \mathrm{~m} /$ detik. Nilai laju aliran serentak tersebut memenuhi persyaratan laju aliran berdasarkan SNI 037065-2005 yaitu minimum 0,9 m/detik sampai maksimal $2 \mathrm{~m} /$ detik. Perbandingan kecepatan aliran (software) dengan persyaratan SNI 03-7065-2005 ditunjukkan pada tabel 9 .

Tabel 9. Perbandingan kecepatan aliran fluida serentak (software) dengan persyaratan kecepatan aliran (SNI 03-7065-2005)

\begin{tabular}{|c|c|c|}
\hline No & $\begin{array}{c}\text { Kecepatan aliran - } \\
\text { software (m/detik) }\end{array}$ & $\begin{array}{c}\text { Persyaratan } \\
\text { Kecepatan aliran - } \\
\text { SNI 03-7065- } \\
2005 \text { (m/detik) }\end{array}$ \\
\hline 1 & 1,530 & $0,9-2$ \\
\hline
\end{tabular}

Pada tabel 6 di atas yang menunjukkan bahwa nilai tekanan fluida setiap node (tekanan setiap output) menggunakan software kemudian dibandingkan dengan tekanan fluida berdasarkan persyaratan SNI 037065-2005 (Alat plumbing: kran) dan BS 6700. Perbandingan tekanan fluida (software) dengan persyaratan minimum tekanan fluida (SNI 03-70652005 dan BS 6700) ditunjukkan pada tabel 10. Pada node 28 (kran wudhu), node 22 (bak cuci pakaian), dan node 27 (bak cuci dapur) menunjukkan bahwa tekanan fluida belum memenuhi minimum persyaratan dari SNI 03-7065-2005 dan BS 6700. Tetapi hanya tekanan fluida pada node 14 (kran taman) dan node 30 (bak mandi) yang memenuhi minimum persyaratan dari SNI 03-7065-2005 (0,5 bar.g ) dan persyaratan BS 6700 (0,5 -1,5 bar.g). 
Tabel 10. Perbandingan tekanan fluida (software) dengan persyaratan tekanan fluida (SNI 03-7065-2005 dan BS 6700)

\begin{tabular}{|c|l|c|c|c|}
\hline No & $\begin{array}{c}\text { Node } \\
\text { Pipa }\end{array}$ & $\begin{array}{l}\text { Tekanan } \\
\text { fluida - } \\
\text { software } \\
\text { (bar.g) }\end{array}$ & $\begin{array}{l}\text { Minimum } \\
\text { Tekanan } \\
\text { fluida - SNI } \\
\text { 03-7065- } \\
\text { 2005 (bar.g) }\end{array}$ & $\begin{array}{c}\text { Persyaratan } \\
\text { Tekanan } \\
\text { fluida - } \\
\text { BS6700 } \\
\text { (bar.g) }\end{array}$ \\
\hline 1 & $\begin{array}{l}\text { Node } \\
14 \\
\text { (kran } \\
\text { taman) }\end{array}$ & 0,7050 & 0,5 & $0,5-1,5$ \\
\hline 2 & $\begin{array}{l}\text { Node } \\
30 \text { (bak } \\
\text { mandi) }\end{array}$ & 0,5111 & 0,5 & $0,5-1,5$ \\
\hline 3 & $\begin{array}{l}\text { Node } \\
28 \\
\text { (kran } \\
\text { wudhu) }\end{array}$ & 0,3662 & 0,5 & $0,5-1,5$ \\
\hline 4 & $\begin{array}{l}\text { Node } \\
22 \text { (bak } \\
\text { cuci } \\
\text { pakaian } \\
\text { ) }\end{array}$ & 0,3431 & 0,5 & $0,5-1,5$ \\
\hline 5 & $\begin{array}{l}\text { Node } \\
27 \text { (bak } \\
\text { cuci } \\
\text { dapur) }\end{array}$ & 0,1178 & 0,5 & $0,5-1,5$ \\
\hline
\end{tabular}

\section{KESIMPULAN}

Setelah dilakukan perhitungan dan komputasi instalasi sistem plumbing air bersih rumah tipe 42 maka dapat disimpulkan sebagai berikut:

a. Jumlah kebutuhan air pada rumah tipe 42 yaitu sebesar 432 liter/hari dan nilai laju aliran serentak $0,0003 \mathrm{~m}^{3} /$ detik belum memenuhi minimum persyaratan laju aliran kebutuhan berdasarkan SNI 03-7065-2005 dan BS 6700.

b. Kecepatan aliran serentak berdasarkan software yaitu $1,530 \mathrm{~m} /$ detik. Nilai laju aliran serentak tersebut memenuhi minimum persyaratan laju aliran berdasarkan SNI 03-7065-2005.

c. Nilai tekanan fluida setiap node (tekanan setiap output) yang menggunakan software hanya node 14 (kran taman) dan node 30 (bak mandi) yang memenuhi minimum persyaratan tekanan fluida berdasarkan SNI 03-7065-2005 dan BS 6700. Selain node 14 (kran taman) dan node 30 (bak mandi) masih belum memenuhi minimum persyaratan tekanan fluida berdasarkan SNI 037065-2005 dan BS 6700.

d. Jenis aliran fluida dalam pipa yaitu jenis aliran turbulen yang memiliki Re $=27078$ (karena memiliki $\operatorname{Re}>4000$ )

e. Setiap instalasi sistem plumbing harus mengacu pada standar yang berlaku agar mampu mengantisipasi kurangnya kebutuhan air, kecepatan aliran air, dan tekanan air sehingga tidak menghambat penyaluran air bersih ke suatu rumah, gedung, atau bangunan lain.

\section{UCAPAN TERIMAKASIH}

Penulis menyadari bahwa penelitian ini tidak dapat terselesaikan dengan baik dan lancer apabila tanpa dukungan berbagai pihak, oleh karena itu pada kesempatan ini penulis mengucapkan terima kasih yang sebesar-besarnya kepada:

a. Bapak Ir. Eko Julianto, M.Sc., MRINA selaku Direktur Politeknik Perkapalan Negeri Surabaya.

b. Bapak Ir. Arie Indartono, M.MT selaku Ketua P3M Politeknik Perkapalan Negeri Surabaya.

c. Bapak George Endri Kusuma, ST. M.Sc.Eng selaku Ketua Jurusan Teknik Permesinan Kapal Politeknik Perkapalan Negeri Surabaya.

d. Keluarga tercinta yang selalu memberi dukungan Penulis menyadari bahwa di dalam penelitian ini masih banyak kekurangan. Segala saran dan kritik membangun dari para penelaah sangat bermanfaat untuk penyempurnaannya.

\section{DAFTAR PUSTAKA}

[1] (2013) Situs Teknik Sipil Indonesia. [Online]. Available: https://www.ilmutekniksipil.com

[2] Morimura, T., dan Noerbambang, S.M, Perencanaan dan Pemeliharaan Sistem Plambing, Jakarta: PT. Pradnya Pramita, 2000.

[3] Tata Cara Perencanaan Sistem Plambing, SNI 037065, 2005.

[4] BS 6700 Design, installation, testing and maintenance of service supplying water for domestic use within buildings and their curtilages - Spesification, British standard, 2006.

[5] White M. Frank, Mekanika Fluida, Jakarta: Erlangga. 1994.

[6] Crane, Flow of Fluids Through Valve, Fittings, and Pipe, Technical paper 410M. New York: Crane Co, 1982.

[7] J. Malau, T. Sitepu, "Analisa pressure drop pada sistem perpipaan fuel oil boiler pada PT. PLN pembangkit Sumatera bagian utara SicanangBelawan dengan menggunakan pipe flow expert", Jurnal e-Dinamis, vol. 3, pp. 164-171, 2012.

[8] Tahara, H dan Sularso, Pompa dan Kompresor: Pemilihan, Pemakaian, dan Pemeliharaan. Jakarta: PT. Pradnya Paramita, 2006. 